\title{
History of Mining in India
}

\author{
A. K. Soni* \\ CSIR-Central Institute of Mining and Fuel Research, Nagpur.
}

(Received 28 May 2020; Revised 20 July 2020)

\begin{abstract}
Mining of minerals is an age-old process continuing since centuries. Indeed, it was started with pick-axe and chisel, way back in pre-Harappan times and pre-Christian era. An insight into the history of mining in India, one of the oldest civilizations of the world, will enable the readers to know how our ancestors were digging minerals from the earth womb with minimum tools and inadequate infrastructure. Describing the history in limited pages is not possible, however, an attempt has been made on the basis of available authentic records. The first third of this paper describes ancient mining and metallurgy in general, encompassing India as well as known ancient civilizations of the world. It is followed by a focussed history of the coal mining industry in India. The third part focuses on mineral-wise excavation history including metallic artefacts like copper, silver and gold with present insight. In brief, this paper attempts to provide a useful insight with reference to India for all readers, directly or indirectly, and whether connected with mining /mineral industry or not.
\end{abstract}

Key words: Ancient time, Civilization, Coal mining, History, Mining, Metal mining.

\section{Introduction}

The history of mining has travelled through many civilizations and cultural eras viz. stone age, dark age, iron age, bronze age etc. and developed as a modern applied science in its present form, from the art and craft of earlier period. From pre-historic times to the present, mining has played an important part in human existence (Madigan 1981, p. 138). Historical records indicate that in the earlier period, 'mining' and 'processing of minerals' were not considered as separate activity. Bare minimum tools and infrastructure resources were used and no machineries were available. Our ancestors were digging minerals from the earth womb with quite an ingenuity. The min-

DOI: 10.16943/ijhs/2020/v55i3/156955

*Email: abhayksoni@gmail.com ing practices in India followed the cultural diversity of the region but were different from other parts of the world. Some interesting aspects of mining and metallurgical history of other countries have been provided by Gregory (1980), Raymond (1984, p. 274) and Lacy and Lacy (1992, pp. 5-23) in the literature on mining.

\section{Mining in Ancient Times}

Mining for obtaining minerals has been in vogue for thousands of years. The Egyptians mined gold as 4,000 years ago, and historical records indicate that the Persians, Greeks, and Romans learned these techniques from the Egyptians. Mining during the Egyptian and early Roman period was carried out by prisoners of war and criminals. In the early days of the Roman Empire, conquests 
of new lands produced many prisoners of war who were available for work in mining and shaft sinking in general. Later when new slaves became less easy to obtain, they became more valuable. Beginning with the reign of Hadrian (138 CE), the Romans began to recognize a degree of individual ownership of mines and permitted the exploitation of some mineral/ore bodies freely. Towards the end of the Roman period, labour laws were passed that mandated improved working conditions for the workers in the mines namely sleeping and bathing accommodations, food, and specific hours of work; shafts/tunnels to be adequately supported with timbers to prevent collapse etc.

The fall of the Roman Empire during the latter part of the 5th century was followed by widespread political and economic chaos that persisted in Europe for more than four centuries (The Dark Ages). The social chaos, incessant warfare, diseases like plague and general economic instability from the 5 th to the 11 th century resulted in a marked reduction in mining. From $1100 \mathrm{CE}-1500 \mathrm{CE}$, the status of the miner did not change much from Roman times. The trade of mining, which included shaft sinking, became a respected profession. During the medieval period, miners in places like Frieburg, Goslar, and Joachimstal were exempted from military service and taxation. English tin miners had the right to prospect anywhere except in churchyards, highways, orchards, or gardens. Such privileges and freedoms were a marked contrast to those of the miners under Egyptian or early Roman rule. 'De Re Metallica' by Georgius Agricola, $1556 \mathrm{CE}$ provides a fairly comprehensive account of mining and shaft sinking techniques that our ancestors had.

In $1168 \mathrm{CE}$, silver was first discovered near the town of Freiberg in Saxony. A silver rush spread across Europe in the late 12th and early 13th centuries, with strikes in Bohemia, Moravia, Hungary, the Alps, and Sardinia. To develop these mines, Saxon workers were normally brought in. One of the greatest silver mines of all time was discovered at Joachimsthal in Bohemiain in 1516 CE. It was in this town that Agricola resided and his book on 'mining and shaft sinking' is based on techniques employed in this area. With growing stability in the 12th to the 16th century, shaft sinking and mining activity increased. In central Europe, the Avars, Czechs, and Saxons mined gold in Bohemia, Transylvania, and the Carpathians. This particular mining revival was led mainly by the Saxons and other German people. The period from antiquity to 1600 CE covered a huge time period with many changes in civilization (Allchin and Alchin 1982, p. 396). However, from the early mining by the Egyptians, Romans etc. through the dark ages/times and then the medieval period, the techniques for mining and sinking shafts changed a little.

\subsection{Mining tools and techniques}

The earliest miners sought flint ${ }^{1}$ for tools and weapons. In ancient time, a form of shallow shafts was commonly being sunk as deep as $30 \mathrm{~m}$ (Stuart 1898) in the chalk beds of northern France and southern England in the neolithic period (8000 BCE to $2000 \mathrm{BCE}$ ). Some Roman shafts were quite deep e.g. the shafts at El Centenillo in Spain went down to 650 feet. Advance rates at the end of this period were probably in the range of 01-02 m per month (Stuart 1898, p. 67).

In the ancient period, only primitive tools of excavations were wedges and picks made from deer antlers and shovels made from the shoulder blades of oxen in the flint mines, in the metal mines stone hammers, antler tools and wooden shovels were used. The waste from shaft sinking was hauled to surface in leather bags or wicker baskets, by one or two men. Firesetting was practiced for assistance in fracturing the rock and making it easier to remove. Czechs and the Saxons used fire quenching as a method of breaking the rock. Ventilation methods were also primitive, often limited to waving a canvas at the mouth of the shaft.

The valleys of the Tigris, Euphrates and Nile were home to the first metal-using cultures. Copper and gold were the first metals gathered in a notable quantity, with copper being particularly important. A civilization using considerable amounts of copper was established in Mesopotamia by about 3500 BCE and in Egypt by about 3000 BCE. Copper was used to make tools and weapons. From Egypt and Mesopotamia, the knowledge of metals spread across Europe. The copper-based cultures of the world were replaced by cultures using bronze by about 1500 BCE. This development led to significant improvement in the quality of weapons and tools. Iron was not successfully smelted until about 1400 BCE.

\footnotetext{
${ }^{1}$ Flint is a hard microcrystalline quartz, a stone that is typically called 'chert' by geologists. This sedimentary rock breaks with a conchoidal fracture.
} 
Underground mining by the Egyptians was carried out over a wide area with two places, in particular, being well known - the Nubian Desert in northern Sudan and the Timna Valley (now Israel). The Greek historian Agatharcides, writing about $200 \mathrm{BCE}$, gives a vivid description of mining under the Egyptians. Agatharcides wrote of fire-setting and breaking of the rock with chisels, miners who wore candles on their foreheads, and of "overseers who never cease with blows." The Egyptian miners who worked both in the mines of Nubia and Timna Valley used metal chisels and hoes and excavated with regular, circular shafts with footholds in the walls for moving up and down. Some of these shafts were over 30 metres deep.

Mining operations in the Timna Valley peaked during 14th to 12th centuries BCE; the main period at Timna is now dated to the Early Iron Age, 1,000 BCE. Egyptian miners of those days apparently wore loin cloths, perhaps headbands and, if a prisoner, ankle manacles. An oil lamp was used for lighting. Fire quenching was the rock breaking method of those days, not at Timna valley. After heating, the rock was doused with water causing it to shatter and become easier to break with bars and wedges. Once removed, the broken rock was placed in baskets, which were carried on worker's back and up the shaft via ladders and footholds cut into the rock walls.

The Romans followed the Greeks as leaders of the then excavation world. Romans explored all around the Mediterranean for mineral wealth to support its rising empire. Digging, deep vein mining, boring and shaft sinking were recorded in Roman literature. Shafts during Roman times were square shaped, small and braced with wood to prevent collapse. Inclined or vertical shafts were necessary to provide access, ventilation, and a means of removal of the minerals and these shafts were not very deep because of occasional collapses. As a whole shaft sinking techniques under the Romans were not very different from those employed by the Egyptians earlier. Generally, hard wood or metallic tools were used to enlarge the fractures in the rock and assist in breaking it away from the rock face. Single- and double-headed hammers were used in combination with pointed bars and wedges. Besides metallic/iron tools, the Romans used fire, to fracture the rock for removal.

\section{Civilization and Mining Advancements}

The history of mining is fascinating and parallels with the history of civilization in different parts of the world (Allchin and Allchin 1982, p. 396). Mining in its simplest form began with Paleolithic humans some 4,50,000 years ago, evidenced by the flint implements that have been found with the bones of early humans from the Old Stone Age (Lewis and Clark 1964, p. 768 ). Our ancestors extracted pieces from loose masses of flint or from easily accessed outcrops and, using crude methods of chipping the flint, shaped them into tools and weapons.

By the New Stone Age, humans had progressed to underground mining in systematic openings $2 \mathrm{ft}$ to $3 \mathrm{ft}$ (0.6 to $0.9 \mathrm{~m}$ ) in height and more than $30 \mathrm{ft}(9 \mathrm{~m})$ in depth (Stoces 1954, p. 1068). However, the oldest known underground mine, a hematite mine (iron ore) at Bomvu Ridge, Swaziland (Gregory 1980, p. 259), is reported from the Old Stone Age and believed to be about 40,000 years old. Early miners employed crude methods of ground control, ventilation, haulage, hoisting, lighting, and rock breakage. Nonetheless, mines attained depths of $800 \mathrm{ft}(250 \mathrm{~m})$ by early Egyptian times. Metallic minerals also attracted the attention of pre-historic humans. Initially, metals were used in their native form, probably obtained by washing river gravel in placer deposits. With the advent of the Bronze \& Iron age, however, humans discovered smelting and learned to reduce ores into pure metals or alloys, which greatly improved their ability to use these metals.

The first challenge for early miners was to break the ore and loosen it from the surrounding rock mass. Often, their crude tools made of bone, wood, and stone were no match for the harder rocks, unless the rock contained crevices or cracks that could be opened by wedging or prying. As a result, they soon devised a revolutionary technique called fire setting, whereby they first heated the rock to expand it and then doused it with cold water to contract and break it. This was one of the first great advances in the science of rock breakage and had a greater impact than any other discovery until dynamite was invented by Alfred Nobel in 1867. Mining, like all other industries, languished during the Dark ages. Number of political upheavals and social developments changed the state of mining and the status of miners from poor to improved. 


\subsection{Mining's contribution to civilization}

The evolution of mining has paralleled human evolution and developed with the advancement of civilization and certainly one of the first industry (Gregory 1980, p. 259) and still getting matured with passage of time. Many milestones in human history-Marco-Polo's journey to China, Vasco-de-Gama's voyages to Africa and India, Columbus's discovery of the new world and the 'gold rushes' that led to the settlement of California, Alaska, South Africa, Australia, and the Canadian Klondike (name of a region in $\mathrm{N}$ W Canada) were achieved with minerals providing a major incentive (Rickard 1932, p. 1068). A chronological development of mining through ages with important world events is outlined in Table 1.

\subsection{Mining advancements}

Two industries, namely mining and agriculture were the primary yet basic industries of early periods, serving the mankind. If we consider fishing \& lumbering as part of agriculture and oil and gas exploration as part of mining, then agriculture and mining continued to supply nearly all of the basic resources used by humans in the past. The order of their contribution interchanged periodically. Mining technology leaped forward during middle period when miners started using explosives to break up large rocks. The Industrial Revolution at the close of the 18th century provided the greatest impact on the use of minerals. With the soaring demand for minerals, came the spectacular improvements in mining processes and technology, especially the use of scientific concepts and mechanization that have even continued to this day.

'Gun powder/Black powder' to 'dynamite' replacement and its use in the mid-19th century is a historical development of the mining industry. During the last two centuries, there has been great progress in mining technology in many different areas. At the same time, advancements were being made in motorized mining tools, such as drills, lifts and steam-powered pumps. Mechanical drills powered by pistons, then compressed air, significantly increased the capability and efficiency of mining for hard rocks. Improvements in other mining processes occurred too. Hand-powered loading and hauling were replaced by electric conveyors, mine cars, and vehicles. Steam-driven pumps solved the problem of water inflow. Candles and oil-wick lamps were improved by gas lamps, and eventually battery-powered lamps. Mechanization and new technology sparked dramatic improvements in mining techniques. In the 20th century, the invention of continuous mining equipment, which extracts the softer minerals like coal without the use of explosives, was perhaps the most notable of these accomplishments. The first continuous miner was tested in about 1940, with its usefulness greatly enhanced by the development of tungsten carbide inserts in 1945 by McKenna Metals Company (now Kennametal). By 1950 'the continuous miner' had started operations to replace conventional coal mining methods and the era of mechanized mining had begun.

In today's technologically-advanced society, mining techniques are progressively improving. For example, using surface mining techniques, many mining operations are now able to extract over 85 percent of minerals and 98 percent of metallic ores. Digging a shaft without endangering the lives of workers is now possible. Newlydeveloped machines used for grinding and crushing can extract minerals from the earth with less energy than ever before.

\subsection{Relation between civilization and mining advancements}

To understand the relationship between history, civilization and mining advancements, mention of precious metal rushes such as 'gold rush' and 'diamond rush' must be made irrespective of the country where they occurred. ${ }^{2}$ These rushes lead to the development of towns, business centres and human settlements in several areas. Gold rushes occurred as early as during the Roman Empire in ancient Egypt. California Gold rush of 1848-49 in the USA is another example. Similarly, history also recorded 'diamond rush', a period of feverish migration of workers to an area where diamonds were discovered. The discovery of a large size diamond ( 83.50 carat) in South Africa in 1871 , led to the foundation of Kimberley mine, and eventually the town of Kimberley. In 1908, the discovery of a diamond near Grasplatz station in Namibia, SW Africa resulted in the development of the town of Lüderitz and several mining settlements. Though no such gold /diamond rush was recorded in India but the development of town /settlement of Robertson Pet, near Kolar gold field (KGF)

\footnotetext{
${ }^{2}$ Wikipedia[https://en.wikipedia.org/wiki/Gold_rush \#Notable_gold_rushes_by_date
} 
Table 1 Ancient mining history : chronological development.

\begin{tabular}{|c|c|}
\hline Date & Event \\
\hline $450,000 \mathrm{BCE}$. & First mining (at surface), by Palaeolithic humans for stone implements. \\
\hline 40,000 & Surface mining progresses underground, in Swaziland, Africa. \\
\hline 30,000 & Fired clay pots used in Czechoslovakia. \\
\hline 18,000 & Possible use of gold and copper in native form. \\
\hline 5000 & Fire setting, used by Egyptians to break rocks. \\
\hline 4000 & Early use of fabricated metals; start of Bronze Age. \\
\hline 3400 & First recorded mining, of turquoise by Egyptians in Sinai. \\
\hline 3000 & $\begin{array}{l}\text { First use of iron implements by Egyptians; Probable first smelting of copper ore with coal by } \\
\text { Chinese. }\end{array}$ \\
\hline 2000 & Earliest known gold artefacts in New World, in Peru. \\
\hline 1000 & Steel used by Greeks. \\
\hline $100 \mathrm{CE}$ & Thriving Roman mining industry. \\
\hline 122 & Coal used by Romans in the present-day United Kingdom. \\
\hline 1185 & Edict by the bishop of Trent gives rights to miners. \\
\hline 1524 & First recorded mining in New World, by Spaniards in Cuba. \\
\hline 1550 & First use of the lift pump at Joachimstal, Czechoslovakia. \\
\hline 1556 & First mining technical work, De Re Metallica, Published by Georgius Agricola, Germany \\
\hline 1585 & Discovery of iron ore in North America in North Carolina. \\
\hline 1600 & Mining commences in eastern United States (iron, coal, lead, gold ). \\
\hline 1627 & First use of explosives in European mines in Hungary (Possible prior use in China). \\
\hline 1646 & First blast furnace installed in North America, in Massachusetts. \\
\hline 1716 & First school of mines established, at Joachimstal, Czechoslovakia. \\
\hline 1780 & Beginning of Industrial Revolution; Pumps used in mines as first modern machines. \\
\hline 1800 & Mining progresses in the United States; Gold rushes help open the west. \\
\hline 1815 & Sir Humphrey Davy invents miner's safety lamp in England. \\
\hline 1855 & Bessemer steel process first used, in England. \\
\hline 1867 & Dynamite invented by Nobel, applied to mining. \\
\hline 1903 & $\begin{array}{l}\text { First low-grade copper porphyry in Utah; Era of mechanization and mass production opens in } \\
\text { U.S. mining with development of the first modern mine (an open pit), subsequent operations } \\
\text { were underground as well. }\end{array}$ \\
\hline 1940 & First continuous miner introduced (an era of mining without explosives). \\
\hline 1945 & Tungsten carbide bits developed by McKenna Metals Company (now Kennametal). \\
\hline
\end{tabular}

Source: Hartman and Mutmnasky 2002.

in Karnataka (India) is a replica of similar rush activity during the British rule.

\section{History of mining in India}

India is a mineral rich country with its own history for coal, copper, lead/zinc and gold mining etc. The mining of the above minerals is described here by dividing the excavated minerals in two broader categories, namely coal and non-coal (metal).

\subsection{Coal mining and Coal industry in India}

The commencement of coal mining dates back to the year 1774 when H.G. Heatly, the British magistrate of Chhota 
Nagpur, together with John Summer, applied for and obtained the privilege of mining coal in Panchet and Birbhum, 125 miles to the north-west of Calcutta. Heatly had six mines in operation in 1777, which produced 90 tons of coal. Heatly was soon transferred to another district and his mining venture came to an end. In 1814, at the suggestion of Warren Hastings, a mining engineer was sent from England to investigate the coal resources of India. He was so much impressed by the prospects that he soon undertook mining at Raniganj on his own. Jones, the engineer, soon died and his mine was taken over by a Calcutta firm. By 1831, this company was producing 14,000-15,000 tons of coal and carrying it by boat to Calcutta. The success of this mine led to greater activity and several new mines were opened in the Raniganj coalfield. However, the overall progress was limited because the demand for coal was small. Large-scale factories had not yet made their appearance and the 'East India Company' arranged coal, which was sent from England to Singapore, Madras, Ceylon by ships. Moreover, the Damodar river, which carried coal to Hoogly, was so shallow that it could be used only during the rainy season and that too by small boats. Under these circumstances, progress could not have been fast. In 1846, the output of coal stood at 91,000 tons. ${ }^{3}$

A new chapter in coal mining was opened in 1854, when rail transport became operational between Calcutta and Raniganj. Around the year 1855, coal mining got acceleration as expanding railways needed an enormous amount of coal as fuel coupled with rapid deforestation making the wood as a fuel dearer. Till 1870, Raniganj coalfield mines were the only ones to be exploited. In 1870 coal was mined in the Kaharbari district of Bengal. After a temporary setback during 1870-75, the industry continued to make slow progress up to 1893-94. While the domestic production was increasing, import also kept rising on account of the rapid extension of railways and inaccessibility of coalfields. Thus, in 1880, India imported about 600,000 tons of coal annually while none was exported. The greatest handicap was high rail and sea freights. The Bengal coalfields were situated far inland thus could supply coal to the limited part of India. However, the number of collieries increased to 123 in 1894, output to 2.80 million tons and the number employed stood at 43,197.

It is from 1893-94 that the industry progressed leaps

\footnotetext{
${ }^{3}$ http: //www . economicsdiscussion.net/india/ industries-india/coal-industry-in-india/21241)
}

and bounds. Even the famines during that period could not affect the fortunes of the coal industry mainly because the railways, its principal consumer, far from suffering from famine, were busier than ever before in transporting food from one part of the country to another. At the same time, there was a distinct change in the policy of the government which decided not to import coal, "at least to any appreciable extent." Efforts were also made to develop coal mines, not in Bengal where private enterprise held the field, but in the central provinces, Punjab and Baluchistan. On Warora mines alone, the government made an outlay of Rs. 18 lakhs in 1899. By 1903, there were 302 coal mines at work of which 279 were in Bengal alone. The capital of joint stock companies was estimated at Rs. 240 lakhs. The output had risen from 1.3 million tons in 1884 to 7.5 million tons in 1903. In 1884, only $68.9 \%$ of the coal consumed by Indian railways was of domestic origin. This proportion gradually rose till, in 1903, 99.2\% was obtained from Indian collieries. Imports of coal declined from 8.4 lakh tons in 1894 to 1.9 lakh tons in 1903; exports, first begun in 1886, increased to 4.4 lakh tons in 1903. Steady though, not continuous progress, was maintained up to the outbreak of the first world war. This was largely due to improved machinery and liberal the grant of mining leases and licenses.

After the end of Second World War in 1945, machinemining started at a slower pace in India, but very large proportion of the output was still done by hand. The Department of Mines and the Mines Board of Health were established in 1893 with their headquarters at Dhanbad and circle headquarters in the Raniganj Coalfield.

Coalfields of Eastern India: The coal-mining in India, operated from different coalfields, first started in 1774 with Raniganj Coalfields. However, the first systematic geological survey of this coalfield was made during 184546 by D. H. Williams, Geological Surveyor to the East India Company, and a more detailed examination on the one-inch to one- mile scale by W. T. Blanford during 1858-60. Some 50 collieries were already in existence and during the period (1858-60) there was an annual average production of some $2,82,000$ tons. In those early days, much of this coal was shipped to Calcutta in-country boats which plied down the Damodar. Difficulties of coal transportation eased with the opening of the East Indian Railway from Calcutta to Raniganj early in 1855 and by its extension, during the next 10 years, westwards to Barakar 
and north-westwards via Sitarampur linking up with the system. By 1868, the five principal companies namely : Beerbhoom Coal Co. Ltd.; Bengal Coal Co. Ltd.; East Indian Coal Company Ltd.; Equitable Coal Co. Ltd. and Gobind Pundit, Siresol were engaged in winning coal in the Raniganj field and together they produced about $88 \%$ of the total output amounting to the tune of 4,92,700 tons approximately (Gee 1940).

In the first hundred years, the Raniganj coalfield was the only, or at least the most important, producer. But towards the end of the 19th century, the large reserves of good quality coal of the Barakar in the Jharia Coalfield became increasingly realized. That area had been geologically examined by T.W.H. Hughes of the Geological Survey of India in 1865, but mining development was not seriously taken up for several years. During the early stages of progress, exploitation of coal was mainly from inclines and quarries but, as the years advanced, the number of pits of a depth of several hundred feet naturally increased, and with the extension of branch railway lines across the field, other areas were opened up.

The 'rise' of the Jharia Coalfield has been dealt by Fox (MGMI 1929) and as he points out, the whole future of the coalfield in those days was depended on railway communication. Following an examination of the area in 1890 by East Indian Railway Company, the Grand Chord line was extended via Dhanbad to Katrasgarh. By 1894 and during the following years the branch line to Patherdih was opened. As a result, during the next decade, mining developed rapidly in Jharia coalfield and the coal output for 1906 exceeded the figure of the Raniganj field (36,50,563 tons), and since then Jharia coalfield has remained the principal coal producing coalfield of India.

A relatively small, though important, Giridih or Karharbari coalfield lying north of Jharia coalfield and some 23 miles west of the East Indian Railway mainline started receiving attention and mining commenced as early as 1857. With the establishment of railway connection with the mainline in 1871, the output of the good quality coking coal of this coalfield increased rapidly. The coal output was derived from the mines of Bengal Coal Company. By 1890, the total tonnage from the Jharia coalfield had exceeded a million mark. Other coalfields in Bengal and Bihar, which were exploited later and in the 19th century, included a small output totalling some 7200 tons from the Barakar measures of the Daling area in the Darjeeling dis- trict, between 1896 and 1900; and on a somewhat larger scale in the Rajmahal and Daltonganj areas of Bihar. In Bihar based coalfields, coal was apparently mined since1842 and continued intermittently in a small way until 1931 (Hompray 1842). In 1901, another railway network was established via the Son Valley, prior to which coal was dispatched in boats down the North Koel river. Better rail and road network facilities were built from 1947 onwards in various coalfields.

Coalfields of central and southern India: The coalbearing areas of central and southern India had been surveyed and reported by the GSI (Geological Survey of India) principally by Hughes, William King and E. J. Jones, between 1860 and 1880. With the development of railways, attention was naturally paid to the possibilities of more mining of coal. In the Central Provinces, the earliest coal mining was done apparently at Mohpani coal block where a colliery was opened in 1862 by the Narbada Coal and Iron Company Limited. With the construction of a railway connection, in about 1870, the output appreciably increased to some 40,000 tons in 1900. The collieries were purchased by the Great Indian Peninsula Railway Company in 1904. In Central India, mining was commenced at Umaria in Rewa state in 1884 and a small production was raised from the Johilla coalfield between 1898 and 1902 . With railway facilities, the Umaria output expanded to nearly 2,00,000 tons in 1903. Further south at Warora (Maharashtra) production commenced in 1874 and rose to a maximum of 153,336 tons in 1902. In 1906, these mines of Warora were abandoned as a result of underground fires. At Mohpani, in the Central Provinces, production ceased in 1926. In erstwhile Hyderabad state, the Singareni coalfield was discovered by William King in 1872 , and the first raising took place some 15 years later i.e. around the year 1887 . Steady progress was made during the remainder of the century and an output of 4,69,291 tons was reached by 1900 .

\section{Coalfields of north-eastern and north-western In-}

dia: In north-eastern India, following earlier mining operations on a small scale, extensive developments took place in the Namdang and Ledo areas in Assam from 1881 onwards when a mining concession was obtained by the Assam Railways and Trading Company. Communication with the Assam- Bengal Railway was soon established and, the output of these Tertiary coal seams rose steadily to a quarter of a million tons annually during the 
next 25 years. In the north-west, near Quetta (now in Pakistan), the mining of the relatively thin Tertiary seams was taken up on a small scale during the final decade of the last century, and was continued by the North-Western railway company for many years. In the Punjab Salt Range, at Baghanwala, the working of a Tertiary coal seam, up to a few feet in thickness, was commenced by the same company in 1893 and maximum output of some 13,000 tons was raised in 1897. On account of the poor quality of the coal, the mines were closed down in 1899-1900. Other mines had previously been started (in 1884) in the adjoining Dandot area by this Company and a maximum production of 81,218 tons was raised in 1899. Since then the production declined and the collieries were handed over to contractors in about 1911. In the year 1900, the total production of these mines of Punjab area was only 74,083 tons. At Palana, near Bikaner in Rajputana (now, Rajasthan) the lignite mining (of Tertiary age) commenced on a small scale in 1898 and production rose to some 45,078 tons in 1904 since then it has declined.

Developments during pre and post-independence: During the pre and post-independence period, a number of coalfields were opened in India viz. Bokaro coalfield (1908), Rampur coalfield and Ib River valley coalfield (1913). In the Central Provinces the Pench Valley coalfield and Kanhan coalfield fields commenced production in 1903 near Chhindwara, M. P. Still further south, the Ballarpur coalfield in Berar was also opened in 1903, increasing the annual coal production during the period.

Increased coal demand on account of rising population resulted in number of new coalfields such as Jaintia coalfield (1915) and Ramgarh coalfield in Bihar (1920), Sohagpur coalfield (1921), Sasti coalfield (1920), Ghugus coalfield (1920) and Shahpur coalfield (1921) in the Central Provinces. Production commenced during 1923-24 in the Karanpura coalfield in Bihar and the Talchir in Orissa. The demand for 'coking coal' increased appreciably with the construction of the iron and steel works at Tatanagar (Bihar) and the blast furnaces at Hirapur during 1922. Subsequently, around 1933 an increased internal demand and a rapid rise of the foreign trade provided more favourable conditions and it began to draw greater attention in the post-independence period.

Setting up of the National Coal Development Corporation (NCDC), a Government of India Undertaking in 1956 with the collieries owned by the railways as its nu- cleus was the first major step towards planned development of Indian Coal Industry. Along with the Singareni Collieries Company Ltd. (SCCL) which was already in operation before independence (since 1945) and which became a Government company under the control of Government of Andhra Pradesh in 1956, India thus had two Government coal companies in the fifties. SCCL is now a joint undertaking of Government of Andhra Pradesh and Government of India sharing its equity in ratio 51:49. Important milestones after the post-independence period can be summarized as (a) Nationalisation of coal mines: The burgeoning energy needs and coal demand and inadequate capital investment from the private coal mine owners, unscientific mining practices and poor working conditions in some of the private coal mines became matters of concern for the Government. The Central Government took a decision to nationalise the private coal mines in two phases, the first with the coking coal mines in 197172 and then with the non-coking coal mines in 1973. In October, 1971, the Coking Coal Mines (Emergency Provisions) Act, 1971 provided for taking over in the public interest of the management of coking coal mines and coke oven plants pending nationalisation. This was followed by the Coking Coal Mines (Nationalisation) Act, 1972 under which the coking coal mines and the coke oven plants other than those with the Tata Iron \& Steel Company Limited (TISCO) and Indian Iron \& Steel Company Limited (IISCO) were nationalised in May 1972 and brought under the Bharat Coking Coal Limited (BCCL), a new Public sector Organization. Another enactment, namely the Coal Mines (Taking over of Management) Act, 1973, extended the right of the Government of India to take over the management of the coking and non-coking coal mines in seven States including the coking coal mines taken over in 1971. This was followed by the nationalisation of all these mines in May 1973 with the enactment of the Coal Mines (Nationalisation) Act, 1973 which now is the piece of Central legislation determining the eligibility of coal mining in India. ${ }^{5}$

The coal mining in India has a long history of nearly 220 years starting from 1774. Raniganj Coalfield along the western bank of river Damodar and Jharia Coalfield in

\footnotetext{
${ }^{4}$ https://www.coal.nic.in/content/ historybackground

${ }^{5}$ Ministry of Coal, Government of India; https : //www . coal . nic . in/content/historybackground/
} 
eastern part of India in the Jharkhand state are the oldest coalfield in India. At present, the commercial coal mining is owned by Coal India Limited and its subsidiaries companies having government control. In addition, Singareni Collieries Company Ltd. (SCCL) and Coal Mines owned by Tata's (West Bokaro) in Jharkhand are also producing coal in India. Historically only government companies were the main producer of coal and the rights of mineral wealth (coal) rest with the central government, solely. Since the coal industry is very large in size and demand of coal always exceeded supply in India, steps to exploit newer coal deposits have been initiated by the government from time to time. Recently, Indian government has opened participation of private sector in coal to boost the indigenous production of coal. Coal supply quotas i.e. coal linkages and the method, organisation of fixing minimum coal prices of selling and buying coal have been established and made transparent. The openmarket sale of coal is now allowed. 'Incentives for quick mining/mine development by private entrepreneurs including 'coal gasification' are some other steps taken in the industry with no difference between captive and noncaptive coal mines. Safety norms and eligibility criteria for miners, mining legislations and guidelines for the operation of mines have strengthened the entire Indian coal mining sector in the post-independence era.

\subsection{Metal mining in India}

The references to gold, silver and other metals have been found in early Indian literature like Mahābhārata and Rāmāyana. Earlier around 10th century BCE, metal was simply called bright metal or hiranya. It was then divided into yellow bright metal, i.e. gold (harita-hiranya), and shining bright metal, i.e. silver (rajata-hiranya) and base metal (ayas). The base metal was further divided into red ayas i.e. copper, and black ayas i.e. iron. Silver and iron were newcomers and regarded as inferior to their counterparts, gold and copper. Iron, copper, silver, gold, zinc, lead, bronze, brass, etc. were used since the early period and metallurgy of extracting these metals was without any advance tools and techniques. ${ }^{6}$

The Satapatha Brāhmṇna and Atharvaveda speak of gold as having everlasting lustre and held in high es-

\footnotetext{
${ }^{6}$ https://www.ancient.eu/Indus_Valley_Civilization; https://www.livehistoryindia.com/cover-story/2020/ 01/30/ harappa-raising-a-civilisation
}

teem in the society. The writings of Manu, Yajnavalkya and Patanjali of the pre-Christian era refer to bronze and brass. Both Kautilya's Arthaśāstra and the earliest Indian brass of Taxila belonged to fourth century BCE, while the earliest $14 \mathrm{C}$ date of Zawar Mine is $430+100$ BCE. The Arthaśāstra provides the earliest firm literary evidence for the production of metallic zinc on a regular basis in India, which mentions brass as arkuta and refers to burning of a rasa (metal) to produce an eye salve or 'zinc'. It also records how various metals were obtained e.g. tutthodgata (silver) was extracted from tuttha after seventeen times refinement. Zinc was exported to Europe in the middle of the seventeenth century CE from China under the name totamu or tutenag. Tutenag possibly has its origin in the word 'tutthandga' - a name of 'zinc' in south Indian languages as mentioned. A 17th century Chinese author has written that 'tutenag' is a word from some foreign language. Totamu or tutenagis, very similar to lead meaning 'poor lead'. But it is not known how it was obtained. By the early centuries of the Christian era, the Ayurvedic practices were very common in the society and the metals were used in the preparation of Ayurvedic medicine also. According to the Rajputana Gazetteer of 1908, the only precious or semi-precious stones worked at that time was 'garnets' which occur in the Aravalli schists at several places in the Bhilwara Zila of Rajasthan (Erskine 1908). In Kishangarh state of that time also, garnet of good quality was excavated. Agate, Jasper and Amethyst, of no great value, in calcareous rock and quartzitic rocks were sporadically mined in the valley of Udaipur and other parts of Rajasthan. In this period of late 1800 and early 1900, the extensive workings for gold mining in Hutti Gold Mines in Raichur and base metals at Rajpura-Dariba commenced. It is realized that this century's early period was conceivably 'a grey area', in the annals of mining. Figure 1 depicts Bronze utensil of 1867 representing the metal uses of old period. $^{7}$

Gold: Underground mining for gold has hoary traditions in India, perhaps to some 2000 years old, as evidenced by the dating of charred timber logs from Hutti Gold Mines of Karnataka. The gold mining activities continued in different parts of South India and perhaps also in Chota Nagpur in the ancient period. The auriferous regions in Karnataka state appeared to have been systematically ex-

\footnotetext{
${ }^{7}$ https : //www.reddit. com/r/IndiaSpeaks/comments/
} cjco72/undivided_indias_map_on_brass_plate_1867 


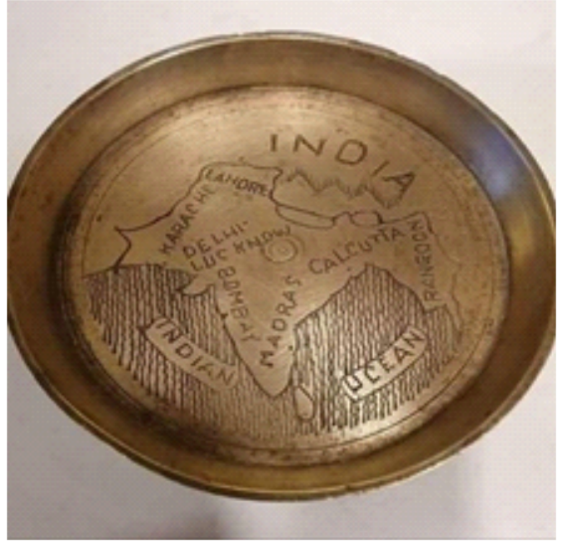

Figure 1 Bronze utensils of 1867.

plored by the ancient miners, and had been worked to considerable depths. At Hutti, for example, narrow gold reefs were worked by ancients to a length of some $1500 \mathrm{~m}$ and to a depth of $190 \mathrm{~m}$ by fire-setting alone. The active mining for reef gold was going on in many of the goldfields of southern India, such as Bellari, Kabligatti, Waynad and elsewhere, during the reign of Vijayanagar Kings (13361560) and later during the regime of King Tipu Sultan. Kolar Gold Field (KGF) is a historical mining landscape/ region which had produced tonnes and tonnes of gold by Bharat Gold Mines Limited (BGML) formerly called as Bharat Earth Movers Limited or BEML (Figure 2).

KGF is located at about $30 \mathrm{~km}$ from Kolar town and $100 \mathrm{~km}$ from Bangalore. Robertson Pet is the headquarters of KGF in Sadwa taluka of Kolar district in the Karnataka state of India. This mining town is well known for 'gold mining' for over a century. At KGF, the gold mining was very deep (about 2 miles 38 feet) and challenging. Though, new veins of gold ore were discovered periodically, but it was not easy to take out ore with very less gold content at a profitable rate hence decision to close down mining was taken in 2001. Champion reef, Nundydoorg and Mysore mines (all underground mines) were producing the gold ore when KGF was closed. In the postindependence era after 1947 and before its closure, KGF became a cosmopolitan town of Karnataka. Early history of the KGF was compiled by Superintendent of the Wesleyan Tamil Mission, Bangalore and BGML. These studies have been published in the journal of the mythic society.

In the year 1902, electricity was supplied for the mining operations at KGF, from India's first and oldest power generation plant which was called the 'Kaveri Electric Power
Plant' (Figure 3). After India's independence, the then prime minister approached world bank for loan, for India's development purpose, but world bank declined the request citing insufficient security. It is told that Prime Minister said, India has a valuable asset i.e. KGF, and he pledged KGF and got the loan- such was the value and importance of KGF.

Copper: Copper ore and native copper (an un-combined raw form of copper that occurs as a natural mineral) was in use since historic times. Copper is one of the few metals that occur in native, oxidized, and mixed form with other elements like zinc. Copper was the first metal extracted from its ores. The mining of native copper began in Asia Minor before the 6th millennium BCE (Alexander 2001). The first copper produced from smelting copper oxide ores (malachite) and reduced using charcoal appeared about 4000 BCE in Asia Minor. The technique reached Europe towards $3500 \mathrm{BC}$ and the Indus Valley (today Pakistan) around 3000 BC. The oldest copper object ever found (native copper nugget) was over 10,000 years ago (Alexander 2001).

The samples from old copper workings of Rajasthan, Gujarat and Andhra Pradesh on carbon dating have yielded $14 \mathrm{C}$ date of which the earliest going back to Mauryan time (c.300 BCE) and the latest to the early medieval period (c. $1000 \mathrm{CE}$ ) (Agrawal et al. 1975). Copper metallurgy in India dates back to the beginning of the 'Chalcolithic cultures' in the sub-continent (Hegde 1981). The Chalcolithic metal samples of that period revealed that the abundant Chalcopyrite of Aravallis in Rajasthan, had poor grade, containing the traces of arsenic, antimony and sulphur. Some old copper coins of the later Kushan type, found at Rakha mines, belonging to 16th century or earlier (Hegde 1991, p. 86).

Mining of copper has a very long history in India although, it is almost impossible to locate precisely ancient mining sites from where the copper ores were originally exploited during a specific period. The existence of copper slag near the ancient mines in many parts of India testifies to the fact that copper mining and smelting was an important industry in ancient India. Though, copper from Rajasthan at Aravallis, Alwar, Bharatpur, Khetri, Udaipur (Shrivastava 1999) was reported in nearly all historical records but in Andhra Pradesh, there are at least four districts, Kurnool, Bellary, Nellore and Guntur, where many old workings were found. Copper mines in Nellore are 

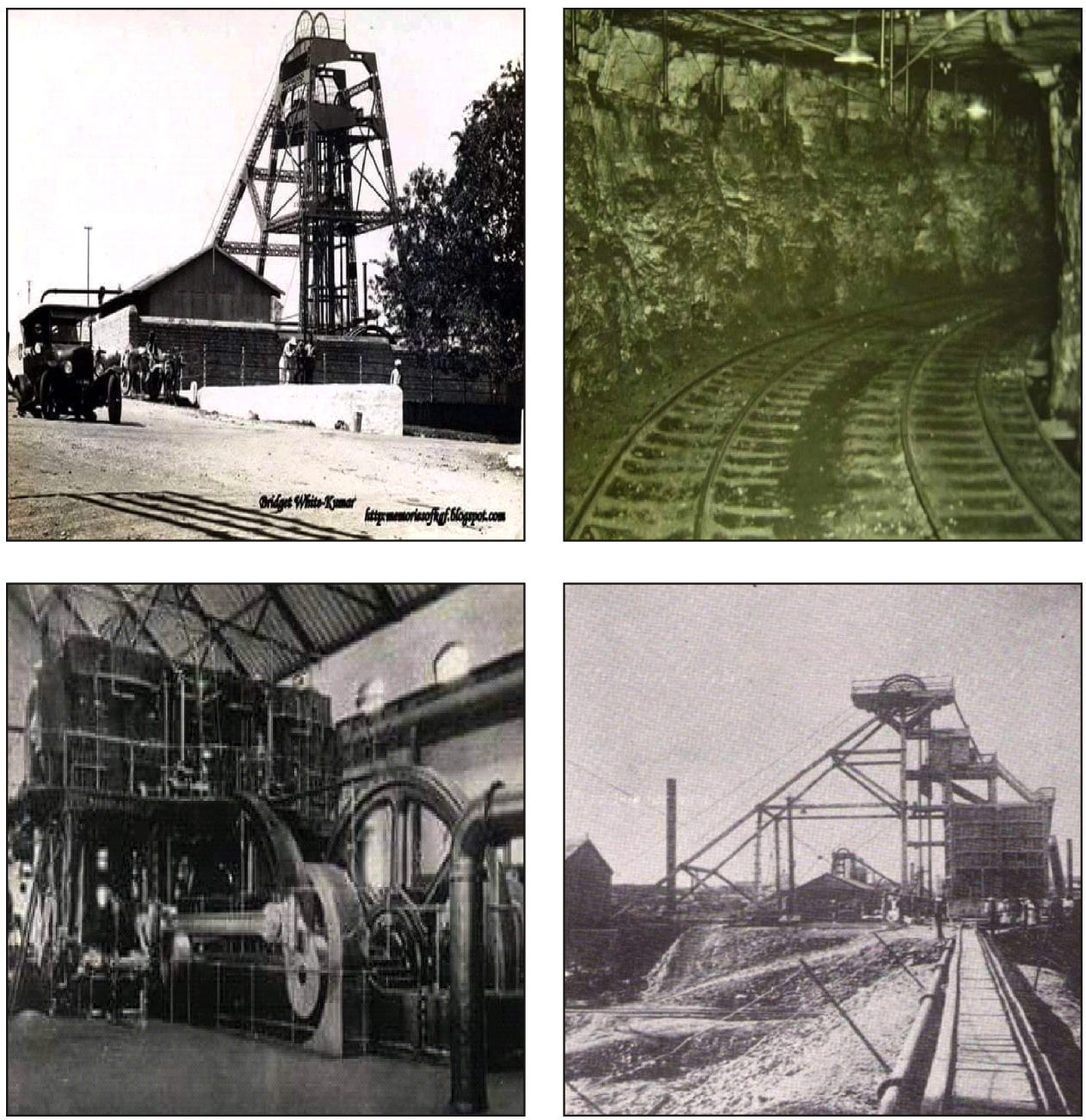

Figure 2 Some old pictures of KGF mine and its installations.

at least 100 feet deep and several hundred feet long. In Guntur, there are open trenches following the roads in the direction of the strike (Ziauddin 1961). The occurrence of copper and related old workings in the Balaghat area of Madhya Pradesh and the Kumaon-Garhwal belt of Uttar Pradesh provides evidence of its use in ancient times. The copper implements found at Gungeria points towards Balaghat as its obvious source (Neogi 1979, p. 77; Shrivastava 1999). The traces of old copper mines are apparently abundant in the Kumaon-Garhwal belt which is located just north of the Gangetic plain and must have been the main copper source to the copper using cultures of the upper Gangetic valley (Ball 1881, p. 267).

There are indications of the mining and smelting of copper in the Singhbhum district of Bihar, by 'seraks' (a surname of ancient time) or lay Jains, some 2000 years ago.
According to some old unidentified records of 1857, the copper mines in Singhbhum were of the eleventh century period when the kingdom of Orissa flourished. V. Ball of GSI in his Economic Geology of India, records that mining of copper ores in Khetri and other districts of Rajasthan especially at Dariba and Singhania was carried out on a large scale right till the end of the nineteenth century. The precise level of mining activity, during 1400-1800 would however, be a matter of conjecture as no detailed records are available (GSI 1881).The ancient workings for copper near Agnigundala in Guntur district, Andhra Pradesh was first recorded by Heyne in 1814 in his account on Tracts, Historical and Statistical in India. The old workings were spread over a linear belt of more than $3 \mathrm{Km}$ as indicated by remains of rock dumps, pounding stones, washing tanks, tailings dump, smelting furnaces, cupolas etc. It is pos- 


\section{THEN SUPREME AND WHOLE INDIA CAME TO KNOW ABOUT KOLAR FIELDS}

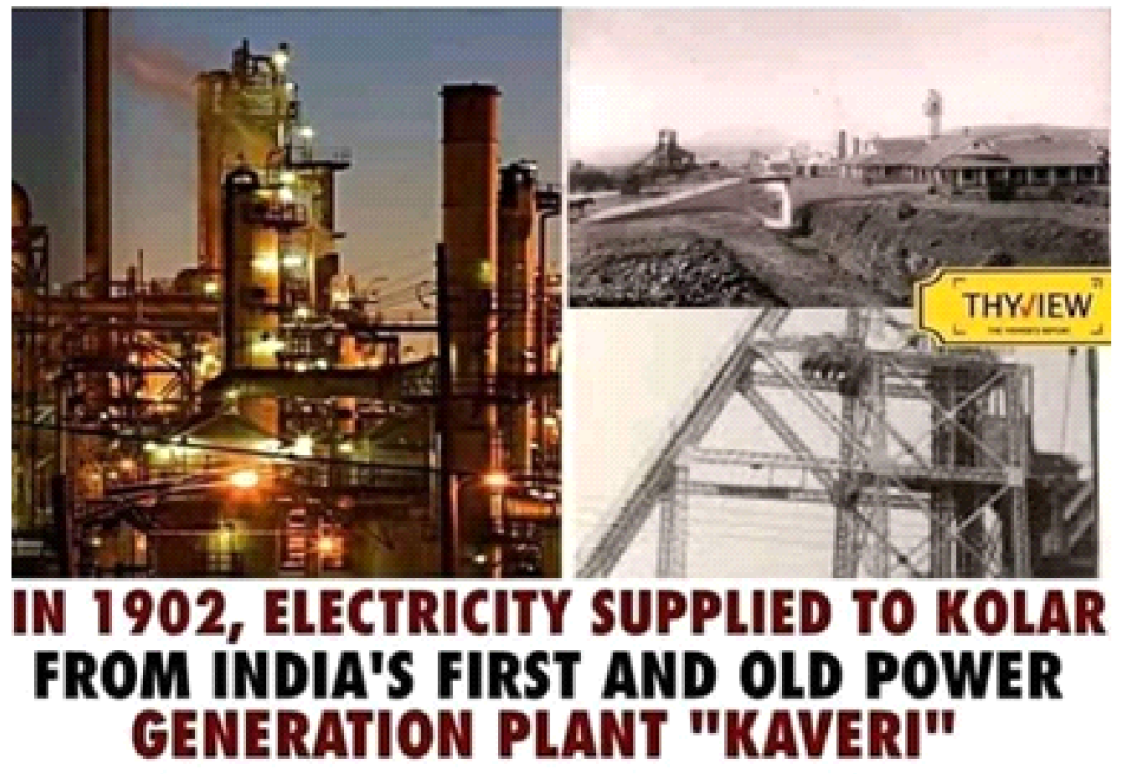

Figure 3 Electricity supply for the mining operations at KGF (1902).

sible that Agnigundala might also have been worked sporadically. The copper deposits of Sikkim were also worked during the medieval times. Casting of guns and cannons during the Moghul period supports the fact that copper was available indigenously during the period 1400-1800. Babar, the first Moghul Emperor, has given an account of the casting of copper gun in his memoir. Many uses of copper metal for coins, clocks, utensils, navigational equipment, musical instruments and decorative items indicate that before and after the Christian era, copper was extracted from the mother earth. The gun of Agra, the Malik-i-Maidan casted in 1584 at Ahmednagar or the Isa Khan's guns in Bengal of the sixteenth century also make evident the availability of indigenous copper. The brass bracelet, necklace and ring of Naga tribes of the north-east show that copper and civilization has close linkages (Figure 4).

Iron: Humans have been using iron for thousands of years dating back to $1200 \mathrm{BCE}$. Even there are references of meteorites as a source of iron before 3000 BCE. Iron Pillar of Delhi that never rusts or corrodes, is an excellent, well-described reminiscence of past showing the excellence of metallurgical know-how of historical period. Historical records of iron ore mining in India are scantly available. Iron appears to have been worked primarily in Alwar in Rajasthan, including the mines of Bhangarh, 3.2 $\mathrm{km}$ from the former capital of Rajawat Rajputs. Iron ore was worked by open workings on the west of a hill, with short irregular adits. The ore consisted of a mixture of limonite, magnetite and oxide of manganese. According to the 1879 work of Medlicott, Blanford and Hume, published by GSI in the state Gazetteer of Rajputana, irregular masses of highly ferruginous material, containing iron were worked at Nimla in Rajasthan, which geologically belonged to Alwar group and Aravallic series of rocks (Raialo limestone). In Eastern India, efforts were made by Motte and Farquher in the Birbhum area (about 1779 to 1789) for mining iron ore but proved abortive.

Historically, much of the iron ore utilized by industrialized societies has been mined from predominantly hematite deposits with around $70 \%$ Fe content in it. The art of making iron and steel from its constituent ore using primitive furnaces such as bloomery, stone-built shaft furnaces, bowl furnaces to present day blast furnaces has witnessed sea change resulting in the production of varieties of iron e.g. wrought iron, cast iron, metallurgical steel and high carbon steel etc.

The existence of iron and its ore, its utilization and 


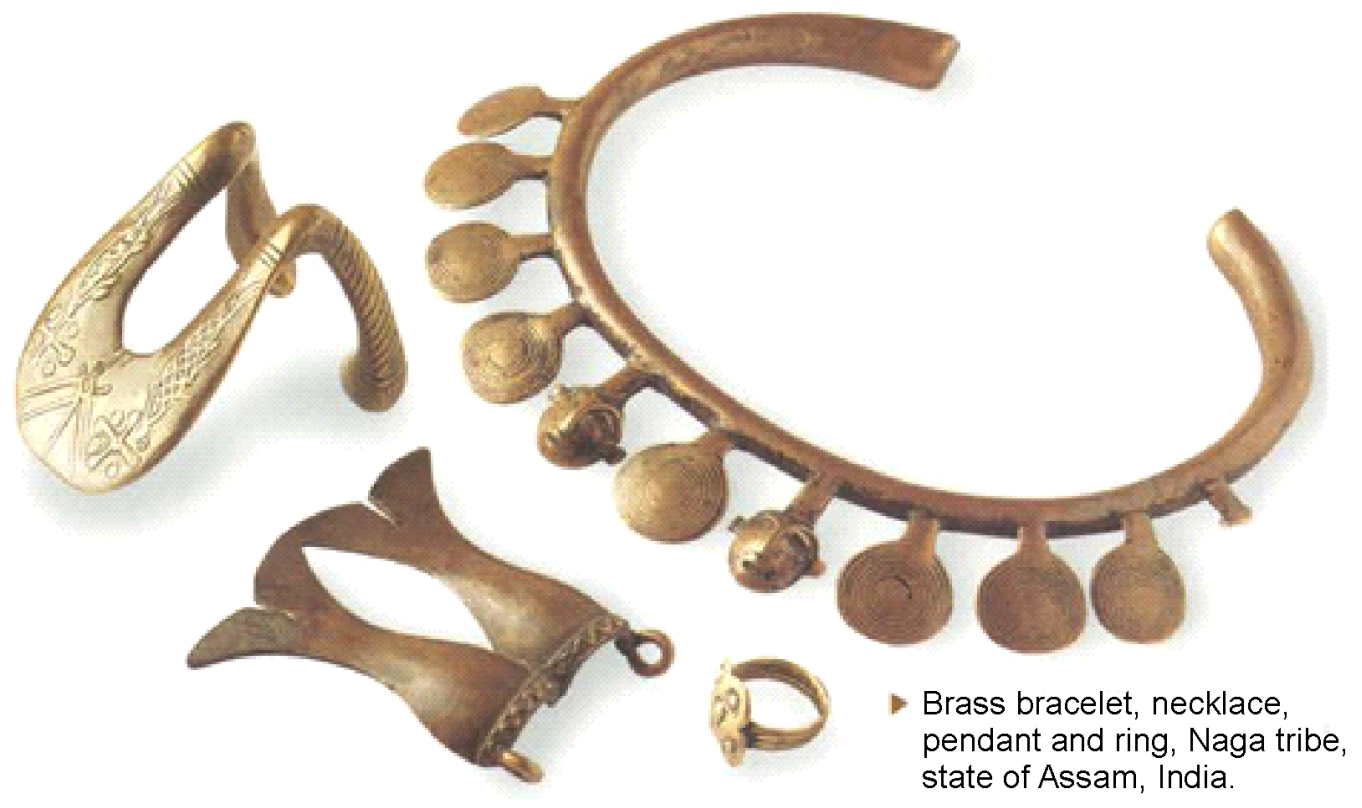

Figure 4 Ornaments of old times used by Naga tribes.

importance right from pre-Rigvedic to the first half of 20th century has been described by Chakrabarti (1976, 1992) and Vaish et al. (2000). Even the Damascus Sword was prepared with indigenous steel making technology. These records offer a comprehensive synthesis of the geological, archaeological, metallographic, literary and ethnographic data on early iron in India, but very limited on ore extraction e.g. the book titled The beginning of iron in India- Antiquity seems important in showing the antiquity of Indian steel-making, examining literary sources and throwing light on the use of iron but not on excavation aspects (Chakrabarti 1976).

Zinc Lead and Silver: In nature, zinc is always found in association with lead, silver and copper. In the northwest India in the state of Rajasthan, commercial deposits of zinc are known to occur since centuries (Straczek and Srikantan 1967). These deposits are found at Zawar mala, Mochia, Balaria, Sindheshwar-Khurd, Rampur-Agucha (Gandhi 1983) and Rajpur -Dariba located in the Aravalli hill ranges.

Mining of lead, zinc and silver, had their heyday during 1400-1800 (Harry 1991). The deposits at Mochia Magra, Balaria at Zawar near Udaipur were probably discovered during the reign of Ranalaksh Singh of Mewar (13821397) and worked until the great famine of 1812-13. Up to 1766 , the mines are said to have yielded a net annual rev- enue exceeding Rs. 2 lakhs. The miners were principally interested in lead and silver, although they were able to smelt rich zinc ores also. The highest concentration of old workings up to a depth of 400 feet have been discovered in the Mochia Magra hill, the site of the present mine (Smith 1963, p. 300). The ore /lode occurs in dolomitic limestone and the hanging walls stand quite well. Captain J. C. Brooke of the Mewar published about mining technology of this mine (Brooke 1850). During this period, yet another lead mining operation was at Taragarh hill in Ajmer. The mine had been in operation for centuries and was exploited by Mahrattas for Rs. 5000/- annually. According to Ajmer Gazetter, the mine was operative in 1818 and produced 10-1200 maunds (One maund $=82$ pounds approx.) of lead (Bagchi and Ghosh 1980).

Brass artefacts containing appreciable amounts of zinc are found from the 2nd, 3rd millennia BCE, whereas those with more than $34 \%$ of zinc are found from the 5 th century BCE, which corresponds to the earliest date of mining at Zawar. These facts together indicate that, although earlier low-zinc brasses were possibly made by the cementation of zinc bearing copper ore, the later high zinc brasses could have been made after the process for the separation of zinc metal was discovered.

The reference to zinc-smelting is found in Rasaratnākara of Nāgārjuṇa, an early medieval text. Ancient 
mines and workings of zinc smelting (slag-heap at Zawar of 7th century CE) were discovered at Zawar in Rajasthan in the eighties by a joint team of scientists from Baroda University and the British Museum. The dating of the slag-heaps indicates that the large-scale production of zinc at Zawar started from the 13th century CE and lasted till the middle of the 18th century CE (Kharakwal 2002, Craddock et al 1983).

According to Biswas (1993), the Indian sub-continent enjoys the unique distinction of being the first to introduce brass and zinc metallurgy to the world. He has documented the process of zinc smelting during the Harappan time. Study of textural records and systematic investigation of ancient relics together suggest that metallurgy of zinc developed much earlier in India compared to China and Europe, where it occurred in the early 18th century. Excavations at Zawar in Rajasthan, India have pointed to the large scale production of Zinc from the 13th century onwards (Deshpande 1996).

Lynn Willies (1984) described in details the old workings at Zawarmalamagra and at Rajpura-Dariba along with old photographic plates, location details and sketch plans. He adopted field visit and carbon dating of the pottery finds associated with these mining sites for verification (Willies, 1983). He suggested that mining took place at considerable depth some 2000 years ago with all problems of water, ventilation and surface workings. Craddock (2017, p. 270) based on archaeological data and analytic results of metallic ore mines, shows that in India, mining was as advanced as those in contemporary Greece and Rome.

Silver: The organization of mines is generally described in Arthaśāstra and more specifically on Silver production. The text seems to be contemporary with the mining operations at Agucha and Dariba which seems to be mainly engaged in assaying and smelting of silver ores. The cupellation process is described in brief with complex instruction and variation in translation. In book 2, chapter 13 verse 10 (Kangle 1965-72, II: 111), it states:

\section{तुत्थोद्वत् गौदिकम् कांबुकम् चाक्रवालिकम् च रूप्यम्}

Tutthodgata, that which is extracted from the mountain, Tuttha; gaudika, that which is the product of the country known as Gauda; $k \bar{a} m$ buka, that which is extracted from the mountain, Kambu; and cākravālika, that which is extracted from the mountain Cakravāla, are the varieties of silver.

The text also underscores that any ruler's success lies in his treasury which has its source in the mines; from the treasury the army comes into being. However, it does not indicate the list for places of mining. The fact that leadzinc mines were known to occur in Rajputana and silver, being the by-product of lead and zinc mining, might have been extracted here. Silver might be exploited near surface deposits Aravalli Hills of Rajasthan (Craddock 2014). The lead-zinc-silver ore of Cerussite $\left(\mathrm{PbCo}_{3}\right)$, containing silver at certain locations and known as gossanised surface deposits occurred in the upper levels of the mines. Later, the major mining excavations were undertaken in Aravallis at Dariba and Agucha.

Precious Stones: References to the working of precious stone/gemstones are found in literature. Āin-i-Akbarī makes a reference to the Wairagarh diamond mines in the 16 th century. Some diggings for diamond were conducted in the Mahanadi alluvium soil in Orissa as reported by Motte, who was deputed there by Lord Clive in 1766. However, there seems to be no systematic record available. India was the only source of diamonds in the world for over 3000 years till diamond deposits were located in Brazil and South Africa. Garnets, of the Almandite variety were worked in Kishengarh, Rajasthan. Till the beginning of the 17th century, Limodia in Rajpipla continued to be the principal centre for agate cutting. There is much evidence that diamond mining activity was pre-eminent during 17 th century.

The French traveller, Jean Baptiste Tavernier mentions details of three diamondiferous regions of India in his travels account (1665-1669). Diamond mining was worked some $4 \mathrm{~m}$ deep in the alluvials along the bank of river $\mathrm{Kr}$ ishna in Krishna and Guntur district. The famous Hope diamond (67 carats), acquired and sold by Tavernier to Louis XIV in 1642 and the Kohinoor, the Great Moghul Diamond (781/2 carats) presented by Mir Jamla in 1656 to Shah Jahan were mined at Kollur on the right bank of the Krishna in Guntur district. This period of the late 16th century also saw considerable digging for the diamond in the Vindhyan tract near Panna (M.P), which is still an active mining centre. It can be gauged from the remains of old workings that shafts up to a depth of $15 \mathrm{~m}$ were sunk to reach the diamondiferous conglomerate beds, the 'mudda', which was heated up with fire for easy extraction. The alluvial deposits were worked with pits up to a depth 
of about $8 \mathrm{~m}$. Today, National Mineral Development Corporation (NMDC), a public sector government company is the only organised producer of diamond in India from its Majhgawan mine at Panna in Madhya Pradesh.

Aluminium: Aluminium, a recently discovered metal is rarely found in native form, and extracted from 'Bauxite' ore, whose mining is continuing since the last two centuries in India. The history of the ore and metal both dates back to the year 1800 . The name bauxite was given to this aluminous rock by Dufrenoy in 1837 after the French city of Les Baux. The history of mining of the ore and extraction of the metal has been described in detail in a monograph on Bauxite published by IBM (1992, p. 465). The genesis of aluminium ore, its mining and metallurgy including the process of 'bauxitization' have been explained in detail. Many researchers namely Fox, Mallet, Roychoudhury, Rane, Deshmukh, Banerjee, Sahasrabhude, Swaminath, M. G. Rao and P. K. Raman, contributed greatly to the understanding of history and genesis of this metal with different perspective.

\section{Present insight}

Mining has had important repercussions on the organization of work processes as it has left a everlasting impact on the communities concerned before turning into 'the mining heritage'. Describing the history of 'coal mining' has brought forward an insight of the past and literature at a single place. The copper mining at Malanjkhand in Madhya Pradesh; Khetri and Kolihan in Rajasthan and Rakha mine in West Singbhum are some of the present and recent mining ventures carried out on modern scientific lines. Similarly, mining operations of lead and zinc ore is going on in Rajasthan at Zawar group of mines (Mochia/Balaria/Zwarmala \& Baroi), RampurAgucha, Sindheshwar khurd and Kayad mines to extract this metallic ore with silver is a major by-product. Hindustan Zinc Limited (Vedanta group) has become ninthlargest silver producer in the world and its Zawar mines are the largest silver producing mine in the country. Similarly, coal mines across the length and breadth of the country, in several coalfields are producing more than 600 million tons of coal collectively. Other minerals being explored are limestone and dolomite, bauxite (Panchpatmali mine, Koraput, Odisha), manganese (DongriBuzurg, Balaghat, Chikla, Ukwa mine), gypsum, rock salt and numerous other industrial minerals like graphite etc. which are an integral part of human economic activity has had a vivid history. Undoubtedly, the value of history and historical knowledge about minerals and their mining are inherent to human development forming the foundation of our living standard.

\section{Epilogue}

History of mining and its remains are constant reminder to the fact that how our lives have been shaped and the modern civilization came into existence. Published archaeological reports indicate simplicity and practicality inherent in mineral and mining excavations using basic tools and bare minimum infrastructure. It also teaches us that optimization existed there in the exploitation process at that point of time as well. Analysis of the distinctive mining landscapes and their history, developed in-situ (at mining sites), reminds us that there were only three basic activities required to sustain civilization viz. mining, agriculture and manufacturing. In early periods, mining was an art which slowly turned into an applied science. Correlating history with mineral excavation reveals the unfolded edges of past exploring the reasonable human ingenuity involved in the production of the raw materials, including energy, that was essential for the development and modern civilization. It can be concluded that there is a need for major programmes of archaeological excavations and recording for gaining the historical evidences of mining in India.

\section{Acknowledgements}

I would like to acknowledge my organisation, CSIRCentral Institute of Mining and Fuel Research (CSIRCIMFR) for permitting to publish this paper. Indeed, this difficult history oriented research paper, has been evolved out of my thirty long years of association with the Indian mining industry. The referee of this paper (anonymous reviewer), INSA journal officials and my colleagues, whose positive and critical comments, has helped me to improve the overall content of this paper significantly, I am indebted and grateful to them all. 


\section{Bibliography}

[1] Agrawal D. P., Margabandhu C., Shekar N. C. Ancient Copper workings: some new $14 \mathrm{C}$ dates, Indian Journal of History of Science, 11.2 (1975): 133-136.

[2] Alexander Leibbrandt. Civilization and Copper -The Codelco Collection, 2001, p.65.

[3] Allchin Bridget and Allchin Raymond. The Rise of Civilization in India and Pakistan, Cambridge University Press, 1982.

[4] Bagchi S. and Ghose A. K. History of mining in India - CIRCA 1400-1800 and technology status, Indian Journal of History of Science, 15.1(1980): 25-29.

[5] Ball V. A Manual of Geology of India, Part III: Economic Geology, Geological Survey of India Publication, 1881, pp. 16-27 and 267.

[6] Biswas A. K. The primacy of India in ancient Brass and Zinc metallurgy, Indian Journal of History of Science, 28.4 (1993): 309-330.

[7] Brooke J. C. Journal of Asiatic Society of Bengal, Vol. XIX (1850): 212-215.

[8] Chakrabarti D. The Early use of Iron in India, Oxford University Press, 1992, p. 200.

[9] Chakrabarti D. The beginning of iron in India, Antiquity, 50.198 (1976): 114-124.

[10] Craddock P. T. Early Indian Metallurgy: The production of Lead, Silver and Zinc through Three Millennia in North West India, Archetype Publications, London, 2017.

[11] Craddock P. T., Eckstein K. Production of brass in antiquity by direct reduction. In: Craddock P.T. \& Lang J. (Eds.), Mining and Metal Production Through the Ages, British Museum Publications, London, 2003, p. 216-230.

[12] Craddock P. T., Gurjar L. K. and Hegde K. T. M. Zinc production in medieval India. World Archaeology 15.2 (1983): 211-17.

[13] Craddock Paul. Production of silver across the ancient world, The Iron and Steel Institute of Japan, 54.5 (2014): 1085-1092.
[14] Craddock Paul, Caroline Cartwright, Kirsten Eckstein, Ian Freestone, Lalit Gurjar, Duncan Hook, Andrew Middleton and Lynn Willies. Simple sophistication: Mauryan silver production in north-west India, Technical Research Bulletin, 7 (2013): 79-93.

[15] Deshpande V. A note on ancient zinc-smelting in India and China, Indian Journal of History of Science, 31.3 (1996): 275-279.

[16] Erskine K. D. Rajputana Gazetteers II-A, The Mewar Residency, 1908, p. 53-54.

[17] Gandhi S. M. Rampura-Agucha lead/zinc deposit, Mining Magazine, November, (1983) : 315-323.

[18] Gee E. R. History of coal mining in India, Proceedings of Indian National Science Academy, 106.3 (1940): 313-318.

[19] Gregory C. E. A Concise History of Mining, Oxford, Pergamon, 1980.

[20] GSI. A Manual of the Geology of India, Part -III Economic Geology by Ball V, Geological Society of India, 1881, p. 663.

[21] Harry Falk. Silver Lead and Zinc in early Indian literature, South Asian Studies, 7 (1991): 111-117.

[22] Hegde K. T. M. Scientific basis and technology of ancient Indian Copper and Iron metallurgy, Indian Journal of History of Science, 16.2 (1981): 189-201.

[23] Hegde K. T. M. An Introduction to Ancient Indian Metallurgy, Geological Society of India, Bangalore, 1991.

[24] Hompray J. A description of the coalfield of the Damoodah Valley and the adjacent countries of Beerbhoom and Poorooleah as applicable to the present date 1842, Journal of Asiatic Society of Bengal, XI (1842): 723-739.

[25] Howard L. Hartman and Jan M. Mutmansky, Introductory Mining Engineering, Wiley Student Edition, 2002.

[26] IBM, Monograph on Bauxite (Revised Edition), Indian Bureau of Mines. Ministry of Mines (Govt. of India), Nagpur, November, 1992. 
[27] Kharakwal J. S. Zinc Production in Ancient India, Infinity Foundation Paper, 2002.

[28] Lacy W. C., and Lacy J. C. History of mining, IN: SME Mining Engineering Handbook, Second edition, Edited by H. L. Hartman, Society for Mining, Metallurgy, and Exploration, Littleton, Colorado, 1992.

[29] Lewis R. S. and Clark G. B., Elements of Mining, 3rd edition, John Wiley \& Sons, Inc., New York, 1964.

[30] Lynn Willies, Craddock P. T., Gurjar L. J. and Hegde K. T. M. Ancient lead and zinc mining in Rajasthan, India, World Archaeology, 16.2 (1984): 222-233.

[31] Madigan R. T. Minerals and Man, Australasian Institute of Mining and Metallurgy, Parkville, Australia, 1981.

[32] MGMI, Transaction of Mining, Geological and Metallurgical Institute of India Calcutta, Vol. XXIV, 1929, pp. 97-105.

[33] Neogi P. Copper in Ancient India, Janaki Prakashan, Patna, 1979..

[34] Raymond R. Out of the Fiery Furnace, Macmillan, Melbourne, Australia, 1984.

[35] Rickard T.A. Man and Metals, Vol.1 \& 2, McGrawHill, New York, 1932.

[36] Shrivastava Rina. Mining of Copper in ancient India, Indian journal of History of Science, 34.3 (1999): 173-180.

[37] Smith Arthur W. The Geology and Mineralisation of the Zawar Lead-Zinc Deposit, India, unpublished Ph.D Thesis, University of London (Royal School of Mines, Imperial College, London), 1963.

[38] Stoces B. Introduction to Mining, Lange, Maxwell, and Springer, London, 1954.

[39] Straczek J. A. and Srikantan B. The geology of Zawar zinc-lead area, Rajasthan, India, Memoirs of the Geological Survey of India, Vol. 92, 1967.

[40] Stuart John M. Mining: Its theory and practice, New York, 1879.
[41] Vaish A. K., Biswas P. K., Goswami N. G., Krishnan C. S. S. and Ramachandra Rao P. Historical perspective of iron in ancient India, Journal of Metallurgy and Materials Science, 42.1(2000): 65-74.

[42] Willies L. Report of a preliminary investigation of ancient mining in the Udaipur district of Rajasthan, Peak District Mines Historical Society, 8.4 (1983): 262-268.

[43] Ziauddin M. Ancient copper mining near Agnikundala, Indian Minerals, 15 (1961): 177. 